\author{
Marjan Markovik \\ University "Ss. Cyril and Methodius" of Skopje \\ Faculty of Philology "Blaže Koneski" \\ Skopje-Macedonia
}

\title{
The Aromanian Farsheroti Dialect - Balkan Perspective
}

7 he author presents the results of mutual Aromanian-Albanian-

1 Macedonian contact with a focus on the analysis of the Aromanian Farsheroti dialect of the Ohrid-Struga region, which has never been a subject of a separate linguistic study. This dialect is described in comparison with the Macedonian Ohrid-Struga dialects and special emphasis is given to their shared contact-induced phenomena in the Balkan context. Using such an approach, the resulting parallel structures and the differences between these dialects are more clearly indicated, thus giving a broader and more detailed picture of the processes typical of the Balkan linguistic league.

According to Weigand's (1891) and Capidan's (1932) basic classification, the Aromanian dialects are divided into following subgroups: the Northern group, which includes the Grammos and the other Albanian groups, the Southern group - comprising the Pindus group which includes the dialect of the Olympus Aromanians, and the distinctive Farsheroti Aromanians dialect. However, today we cannot distinguish Aromanian dialects strictly on the basis of their geographical location but we should also take into consideration their family groups. The migrations of the Aromanians throughout the Balkan started at the second half of the XVIII century and continued until the first half of the XX century. In this period in the places that were inhabited by the Aromanians more layers and different family groups have appeared.

Farsheriots represent a separate group of Aromanians that were mostly shepherds. Their historical provenience is the area around the town of Frasheri in central Albania. It is believed that their actual origins are from mountainous region of Pindus (Capidan 1932). Towards the middle of 
the XIX century, a large group of Aromanians Farsheriots settled in the Ohrid-Struga region. They settled in the villages of the Upper and Lower Belitsa, and a certain number settled also in the villages of Vevchani, Vishni, Podgorci and Labunishta (Трајановски: 1979, 1999). A large group of the Farsheriots is still living in Albania and parts of Greece. With respect to the Aromanian Ohrid dialects, we shall be mostly concentrated on the dialect of the Aromanian - Farsheroti because of the fact that they are represented in a large number in the Ohrid-Struga region, and because their dialect contains several Balkan linguistic features not found in any other Aromanian dialects.

Some Albanian language features have been soundly incorporated into Farsheroti language system. Because of their specifically conservative way of living, they managed to keep those language features that make this dialect different from other Aromanian dialects. Also, they came to the Ohrid-Struga region in Macedonia some 150 years ago from the region of Muzekia in Albania. In that respect their dialect shows certain Albanian properties - mainly in the verbal system. Some of these characteristics were later activated in some innovative processes resulting in the approximation of the Farsheroti dialect to the Macedonian dialect of the region. The same is true with the admirative mood that prof. V. Friedman has discovered in the Farsheroti dialect during our common field research in 1992 (see Friedman: 1994, 1996).

The developments in the nominal system of the Farsheroti dialect also show some Macedonian influence. As a result of this interference, another feature of this dialect became apparent - the simplification of its nominal inflectional system.

At the first part of this paper I will focus on the phonological level and the simplification of the monophthongization of diphthongs in all the positions in the word, as for example: feată $>$ fetă, mul'erea $>$ mul'eri, soare $>$ sori. Later I will talk about the reduction of the vocalic system in the unstressed syllables.

1.

The basic phonological characteristic that differentiates Farsheroti dialect from the Aromanian system ${ }^{1}$ is the absolute loss of diphthongs in all the positions (this refers to the diphthongs with $\underline{\mathbf{a}}$ as a second component).

\footnotetext{
1 As a model of the so called General Aromanian System I am using here the Krushevo Aromanian dialect because of fact that: firstly, according to the origins of the Aromanians from this region and from the other regions in Macedonia, this dialect is most often used as the common model for the Aromanian language, and secondly because of the monographic description of Gołąb (1984) which provides an excellent image of this dialect and efficiently explores the structure of the Aromanian.
} 
Consequently, we could say that some tendencies for diphthongs loss, which were registered by Gołąb (1984) and by some other Aromanian descriptions, have already been developed and included into the system.

Here are some examples, which show monophtongization of diphthongs (see Table 1)

\section{Phonological level:}

the monophtongization of diphthongs Aromanian Krushevo

T1

ò Aromanian Farsheroti

ò

\begin{tabular}{|c|c|c|c|}
\hline \multirow[t]{4}{*}{$/ \mathrm{ea} /$} & 'feată & 'fetă & girl \\
\hline & 'seară & 'seră & evening \\
\hline & vi'deare & vă'deri & seeing \\
\hline & tră'dzeare & tră'dzeri & pulling \\
\hline \multirow{5}{*}{ /oa/ } & & & \\
\hline & 'oaǐe & 'ořă & sheep \\
\hline & 'oară & 'oră & hour \\
\hline & 'poate & 'poti & can, be able \\
\hline & s'koate & s'koti & remove \\
\hline
\end{tabular}

In this dialect, monophthongization also occurs at the end of the word. This has impact upon the grammatical meanings that ending vowels have at the morphological level (see Table 1a):

Aromanian Krushevo Aromanian Farsheroti

\begin{tabular}{|l|l|l|l|l|}
\hline 'puntea & 'punte & & bridge \\
\hline mu'ljarea & mu'ljare & & woman \\
\hline 'padea & 'pade & & ground \\
\hline 'valea & 'vale & & river \\
\hline
\end{tabular}

In Farsheroti dialect there is also a strong reduction of unstressed syllables: : $a>$ ă, o $>$ u, e $>$ i, and in some cases we have i $>$ ă. Rules of reduction of unstressed syllables from those existing in Aromanian Krushevo dialect are very different here. This means that the vowel reduction in the Farsheroti dialect can also occur at the end of the word, where the final vowel carries grammatical meaning. I would now like to show an example of reduction of the word-final in Aromanian of Ohrid (Farsheroti) which is unchanged in Aromanian of Krushevo, and other Aromanian dialects. (see Table 2) 
the reduction of word-final unstressed $\underline{\mathbf{e}}$ T2 Aromanian Krushevo Aromanian Farsheroti

\begin{tabular}{|c|c|c|}
\hline 'pade & 'padi & ground \\
\hline 'punte & 'punti & bridge \\
\hline 'parte & 'parti & part \\
\hline 'păne & 'păni & bread \\
\hline 'kale & 'kali & road \\
\hline 'vale & 'vali & river \\
\hline a'mare & a'mari & sea \\
\hline mu'ljere & mu'ljeri & woman \\
\hline
\end{tabular}

Those two phonological characteristics of the Aromanian Farsheroti dialect had great influence upon the morphological level. This is most evident with the opposition definite-indefinite. In all Aromanian dialects the definite article for the feminine nouns is vowel $\underline{\mathbf{a}}$ which is part of the new formed diphthong. But in Farsheroti dialect the monophthongizaton causes a loss of the definite marker. Consequently, as we can see from the table 3, a new opposition indefinite-definite is established due to the phonological changes.

Influence of the phonological changes upon the morphology:

Aromanian Krushevo Aromanian Farsheroti

\begin{tabular}{|c|c|c|c|c|}
\hline definite & indefinite & definite & indefinite & \\
\hline 'kale & 'kalea & 'kali & 'kale & road \\
\hline 'vulpe & 'vulpea & 'vulpi & 'vulpe & fox \\
\hline 'punte & 'puntea & 'punti & 'punte & bridge \\
\hline 'minte & 'mintea & 'minti & 'minte & mind \\
\hline pă'dure & pă'durea & pă'duri & pǎ'dure & valley \\
\hline mu'ljere & mu'ljerea & mu'ljeri & mu'ljere & woman \\
\hline
\end{tabular}

We can see that the indefinite form in Krushevo dialect is the same as the definite form of the Farsheroti dialect. This shows how phonological changes can influence morphology. This phenomenon proves that in a so called language microsystem there are inner rules whose primary target is to facilitate the communication between the speakers of this particular microsystem and which show certain independence in its development.

2.

As a result of the mutual Macedonian-Aromanian interference, another feature of this dialect became apparent - the simplification of its nominal 
inflectional system. The developments in the nominal system of the Farsheroti dialect show some Albanian influence. The main parallelism in the Farsheroti nominal system is the simplification of the definite article form.

Other Aromanian dialects have the definite article desinence -lu after nouns with endings $-\mathrm{C}^{\mathrm{u}}$, $-\mathrm{Vu},-\mathrm{CV}$;

But only Farsheroti Aromanian has the desinence -u after nouns with endings $-\mathrm{C}^{\mathrm{u}},-\mathrm{CCu},-\mathrm{Ca},-\mathrm{Vu},-C^{\prime} \mathrm{V}$;

\begin{tabular}{|c|c|c|c|}
\hline \multicolumn{2}{|c|}{ other Aromanian dialects } & \multicolumn{2}{|c|}{ Farsheroti Aromanian dialect } \\
\hline non def. & definite & non def. & definite \\
\hline p'reftu & p'reftulu & p'reft & p'reftu \\
\hline pom $^{u}$ & pomlu & pom & pomu \\
\hline băr'bat" $^{u}$ & băr'batlu & băr'bat & băr'batu \\
\hline pă'rumbu & pǎ'rumbulu & pă'rumb & pă'rumbu \\
\hline 'džungu & 'džungul" & 'džung & 'džungu \\
\hline kăsǎ'bă & kăsǎ'bălu & kăsǎ'bǎ & kăsă'bău \\
\hline
\end{tabular}

These examples are related to Albanian masculine nouns with ending in $-\mathbf{k},-\mathbf{g},-\mathbf{h}$, and stressed syllable:

\begin{tabular}{|c|c|}
\hline \multirow{2}{*}{\multicolumn{2}{|c|}{ Farsheroti Aromanian: }} \\
\hline & \\
\hline mik - miku & pork - porku \\
\hline shok - shoku & korb - korbu \\
\hline zog - zogu & pulj - pulju \\
\hline krah - krahu & an - anu \\
\hline bari - bariu & andži - andžiu \\
\hline njeri - njeriu & băfčă - băfčău \\
\hline ka - kau & bo7 - bou \\
\hline
\end{tabular}

In the case of feminine nouns we can speak about similarities not only between Farsheroti Aromanian and Albanian, but also between Aromanian and Albanian in general. Such is the opposition definite - nondefinite in the feminine nouns with ending in -ă in Aromanian, and - ̈ë in Albanian:

Albanian:

$\begin{array}{lll} & \text { feminine } & \\ \text { vajzë - vajza } & <\text { девојка }> & \text { fetă - feta } \\ \text { nënë - nëna } & <\text { мајка }> & \text { dadă - dada } \\ \text { derë - dera } & <\text { врата }> & \text { portă - porta } \\ \text { orë - ora } & <\text { саат, час }> & \text { oră - ora } \\ \text { dorë - dora } & <\text { рака }> & \text { mănă - măna } \\ \text { frikë - frika } & <\text { страв }> & \text { frikă - frika }\end{array}$


This doesn't mean that phonetical similarities result form direct interference between the two languages, but in global frames we can see one tendency of simplification of the opposition definite - nondefinite in Farsheroti Aromanian which shows some similarities with Albanian.

3.

Aromanian Farsheroti dialect shows also certain differences from other Aromanian dialects in the expression of the category of case.

One of the most interesting phenomenon in a nominal system can be seen at the morphological level were the genitive-dative case endings are lost - a situation uncommon for the Aromanian dialects and known to the Meglenoromanian only (Atanasov 2002).

The process of loosing of the case endings (desinences) is completed with the masculine nouns both in singular and in plural, while the feminine nouns, which in singular end with -ă, show a modified ending $-i$ (corresponding with -ljei in Romanian and in other Aromanian dialects). Also the preposition signaling the Genitive-Dative case relation varies, depending on the grammatical gender: it is $\boldsymbol{a l}$ with masculine and ali with feminine nouns.

\section{The loss of the case desinences:}

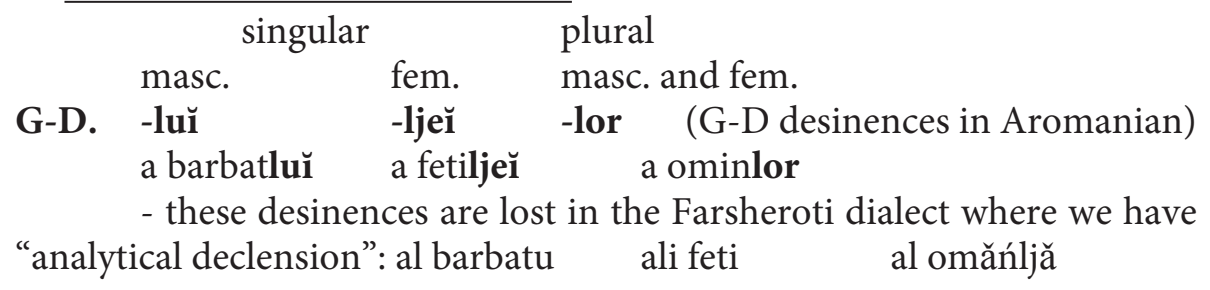

Examples:

\begin{tabular}{|c|c|c|}
\hline $\begin{array}{l}\text { Aromanian } \\
\text { Krushevo }\end{array}$ & Aesta ĭaste kasa a fetiljĕ. & Va s-u-adukă hiljisa a văsileluı̆. \\
\hline Farsheroti & Aista 'esti 'kasa ali feti. & U s-u-adukă hiljăsa al caru. \\
\hline Macedonian & Ова е куќата на девојката. & Ќ ја донесе ќерката на царот. \\
\hline $\begin{array}{l}\text { Aromanian } \\
\text { Krushevo }\end{array}$ & Li dzăk a muljerě̆. & Ilj dzăsiră a ominlor s-fugă. \\
\hline Farsheroti & Li dzăk ali muljeri. & Ilj dzăsără al omăńljă s-fugă. \\
\hline Macedonian & И велам на жената. & Им рекоа на луѓето да си одат. \\
\hline $\begin{array}{l}\text { Aromanian } \\
\text { Krushevo }\end{array}$ & $\begin{array}{l}\text { Năs ía're 'multu harasit }{ }^{u} \text { di } \\
\text { mušuteaca a horăljei. }\end{array}$ & L'i spuš a aisteljě muljere \\
\hline
\end{tabular}




\begin{tabular}{|l|l|l|}
\hline Farsheroti & $\begin{array}{l}\text { Năs a're 'multu hara'sit di } \\
\text { mušuteca ali hori. }\end{array}$ & L'i spuš ali aisti muljeri \\
\hline Macedonian & $\begin{array}{l}\text { Тој беше многу радосен } \\
\text { од убавината на селото. }\end{array}$ & И реков на оваа жена. \\
\hline
\end{tabular}

Thus, the Farsheroti dialect has an analytical declension, identical with the corresponding Macedonian pattern.

4.

In this part I will discuss the compound past tense systems of the Aromanian (Farsheroti) and Macedonian dialects found in the Ohrid-Struga region (Republic of Macedonia). The Ohrid-Struga dialects belong to the West Macedonian dialect group. They are found in the valley region around Lake Ohrid. A large portion of the linguistic particularities of the OhridStruga dialects are the same as those which are found in other Western dialects, and as regards Balkanisms, these dialects show great similarity with the peripheral Western and South-western Macedonian dialects.

Mutual interference is well manifested also in the verbal system of this dialects, especially with the compound past tenses.

The forms of the perfect and pluperfect of these dialects will be presented, and their meanings and functions will be discussed.

Macedonian

\begin{tabular}{|l|l|}
\hline perfect I & sum jadel \\
\hline perfect IIa & imam jadeno \\
\hline perfect IIb & sum jaden \\
\hline pluperfect I & bev jadel \\
\hline pluperfect IIa & imav jadeno \\
\hline pluperfect IIb & bev jaden \\
\hline pluperfect IIIa & sum imal jadeno \\
\hline pluperfect IIIb & sum bil jaden \\
\hline
\end{tabular}

In the Macedonian Ohrid dialect the compound past tenses are formed with forms of the auxiliary verbs (imam/sum) - (habere and esse) and the l- or $\mathrm{n} / \mathrm{t}$ - participle. The perfect (type 1) is constructed with the forms of the present tense of the auxiliary verb sum/esse and the 1-participle, which changes according to gender and number. The perfect (type 2a) is formed with the forms of the present tense of the auxiliary verb imam/habere and the $\mathrm{n} / \mathrm{t}$-participle which does not change, that is, it is found in the neuter gender, singular number, as the most unmarked form. The perfect (type 2b) is built with the forms of the present tense of the auxiliary verb sum/ esse and the n/t-participle, which changes according to gender and number. 
The pluperfect (type 1) is constructed with the forms of the imperfect of the auxiliary verb sum/esse and the l-participle which changes according to gender and number. The pluperfect (type $2 \mathrm{a}$ and $2 \mathrm{~b}$ ) are built with the forms of the imperfect of the auxiliary verbs imam/sum/- habere/esse and the $\mathrm{n} / \mathrm{t}$-participle. The pluperfect (type $3 \mathrm{a}$ and $3 \mathrm{~b}$ ) are constructed with the forms of the perfect of the auxiliary verbs imam/sum/- habere/esse and the n/t-participle.

Farsheroti Aromanian

\begin{tabular}{|l|l|}
\hline perfect a & am mǎ'katǎ \\
\hline perfect b & esk mă'kat \\
\hline pluperfect Ia & a'vem mă'katǎ \\
\hline pluperfect Ib & a'rem mă'kat \\
\hline pluperfect IIa & a'vuř mă'kată \\
\hline pluperfect IIb & fur mă'kat \\
\hline pluperfect IIIa & am a'vută mǎ'kată \\
\hline pluperfect IIIb & am 'fută mă'kată \\
\hline
\end{tabular}

In the Farsheroti Aromanian dialect there also exists a large number of compound verbal constructions. The compound past tenses are built with the forms of the auxiliary verbs (am/esk) - (habere and esse) and the past participle. The perfect (type a) is constructed with the forms of the present tense of the auxiliary verb am/habere and the past-participle, which does not change, that is, it is found in the feminine gender as the most unmarked form. The perfect (type b) is built with the forms of the present tense of the auxiliary verb esk/esse and the past-participle, which changes according to gender and number. The pluperfect (type $1 \mathrm{a}$ and $1 \mathrm{~b}$ ) are constructed with the forms of the imperfect of the auxiliary verbs am/esk- habere/esse and the past participle. The pluperfect (type $2 \mathrm{a}$ and $2 \mathrm{~b}$ ) are built with the forms of the aorist of the auxiliary verbs am/esk- habere/esse and the past participle. The pluperfect (type 3a) is constructed with the forms of the perfect tense of the auxiliary verb am/habere and the indeclinable past-participle, while type $3 b$ is built with the forms of the perfect tense of the auxiliary verb esk/ esse and the declinable past-participle.

Let us examine first the habere/esse perfect, which is common to both dialects and we shall try to determine the functional differences between these two constructions. The perfect, formed with the auxiliary verb imam $+\mathrm{n} / \mathrm{t}$-participle (for Macedonian), and the perfect with am + past-participle (for Aromanian), is most frequent in both dialects. In the Macedonian Ohrid dialect this perfect may be formed from both perfective and imperfective verbs. When it is used with perfective verbs, to a large degree 
a resultative meaning is obtained. The sum-perfect is used most frequently with perfective verbs and the resultative meaning is still more emphasized.

\section{1. habere/esse perfect}

(имам/cyм + participle; am/esk + participle)

Порано имам доаѓано тука. (imperfective verb / indefinitness)

V'lora am vă'nită a'cia.

Имам дојдено и не си одам. (perfective verb / resultativity)

Am vă'nită ši nu mi duk.

Кај тебе сум дојден двапати оваа недела.

Vă'nit esk la 'tini 'dao or a'istă stă'mănă.

Денес сум дојден и ке седам до четврток.

Vă'nit esk as'tazi i u să šăd păn ,lunedi.

The construction of the type habere + participle is a typical Romance construction, which entered into the Macedonian language under Aromanian influence. The process of the adaptation of these constructions is explained in detail by Gołąb in his book The Aromanian dialect of Krushevo Macedonia (Gołąb 1984). As concerns the constructions with sum/esk + the participle, which are represented in both Macedonian and in Aromanian, I think that they appeared because of the need for a clear expression of the opposition perfectivity-imperfectivity in the compound past tenses. This opposition in Macedonian is of a morphological nature, while in Aromanian it is contextual. Thus, the constructions with esk + participle serve as a certain approximation to the Macedonian way of expressing the opposition perfectivity-imperfectivity in the compound past tenses.

\section{1. aspectual difference}

uмaм/am + participle cyM/esk + participle

\begin{tabular}{|c|c|}
\hline $\begin{array}{l}\text { Имам вечерано три саати. } \\
\text { Am cinatǎ trě̆ sǎhăc. }\end{array}$ & $\begin{array}{l}\text { Благодарам, вечеран сум. } \\
\text { Haristo, cinat esk. }\end{array}$ \\
\hline $\begin{array}{l}\text { Имам седено дома два-три саати. } \\
\text { Am šă'dzută a'kasă dŏ́-trě să'hăc. }\end{array}$ & $\begin{array}{l}\text { Седнат сум на столот. } \\
\text { Šă'dzut esk pit skaтпи. }\end{array}$ \\
\hline $\begin{array}{l}\text { Имам доаѓано/одено од Битола } \\
\text { два дена. Am vă'nita/im'natǎ păn } \\
\text { Bituli dao dzăli. }\end{array}$ & $\begin{array}{l}\text { Дојден сум од Битола. } \\
\text { Vă’nit esk păn Bituli. }\end{array}$ \\
\hline
\end{tabular}


The examples of the type cym/esk + participle cannot appear in the form - Вечеран сум три саати; ${ }^{\star}$ Седнат сум на столот два-три саати; ${ }^{*}$ Дојден сум од Битола два дена; where temporal determinant shows durativity, which means that with the constructions with esse + participle, the indicator for (temporal) durativity of the action is blocked and perfective meaning is dominant.

Here are few examples, where we can find aspectual difference between constructions with imperfect or aorist forms of auxiliary am (have):

- imperfective meaning

Додека работев, јадењето се имаше варено.

Păn luk'ram, 'g' ela s-a've 'hertă.

- perfective meaning

Додека работев, јадењето се Uимаше свареноU.

Păn luk'ram, 'g'ela s-Ua'vu 'hertăU.

This process moved in several directions. The basic tendency was towards those verbs which carry in their lexical meaning some signal of perfectivity: momentality, inception, termination, part of some action, or a change of state. These are verbs of the type: to come, to go away, to go in, to come out, to sit down, to stand up, to lie down, etc. Even the Latin periphrastic perfect has been observed to have double meaning (perfective - imperfective) in constructions with verbs of this type (Galton 1976).

This double meaning depended on the context. The situation in Romanian with the "perfect compus" is similar (Mioara 1986). The fact that these verbs in Macedonian are intransitive only facilitated the process of combining them in constructions with esse. Something similar happened with the verbs of the type jadam 'eat'. In the Macedonian language, the opposition perfectivity - imperfectivity with these verbs is of a contextual nature, that is, these verbs are bi-aspectual. Also, depending on the context, they can be both transitive and intransitive because in themselves they can carry an object "večeram - jadam večera" (I dine = I eat diner).

Therefore, it can be said that both in Macedonian and in Aromanian there exists an almost identical use of these constructions, because Macedonian was under great influence from Aromanian and it accepted the Aromanian model, while Aromanian accepted several Macedonian characteristics, above all Macedonian verbal aspect to a large degree.

In the Macedonian Ohrid dialect the 1-perfect (type 1) signifies a nonwitnessed past action, without information concerning the moment of its development. A basic characteristic of the pluperfect is past perfect, i.e., an action which occurred prior to another past action. 
Here, above all we shall concentrate on two other meanings of the l-perfect and pluperfect. The first is the admirative. In the Macedonian Ohrid dialect there are no formal indicators for signifying the admirative, that is, surprise. The Aromanian Ohrid dialect partially took the forms for the admirative from Albanian (where there exists an entire paradigm for the admirative) and adapted them to its own linguistic system. Such forms appear neither in the other Aromanian dialects, nor in Romanian. In the Aromanian Ohrid dialect the admirative is formed by adding the particle "ka" to the participle of the main verb. " $\mathrm{Ka}$ " in reality represents the form of the third person present tense of the Albanian auxiliary verb kam. This particle is fossilized in Aromanian and does not decline according to person and number. The admirative constructions in the Farsheroti Aromanian from the Ohrid-Struga region appear in the present tense and in the compound past tenses.

\author{
admirativity: \\ mac. Tи си бил богат човек!? \\ arom. Tini 'fuska a'vut om!? \\ alb. Ti qenke njeri i pasur!? \\ mac.. $\quad$ Ти си имал голема куќа!? \\ arom. Tini a'vuska 'mari 'kasă!? \\ alb. Ti paske shtepi të madhë!? \\ mac. $\quad$ Тој ја имал вратено колата!? \\ arom. Năs o a'vuska tu'rată 'k' eră!? \\ mac. Виктор бил вратен од Америка!? \\ arom. Viktor 'fuska tu'rat di Amerikă!?
}

The second meaning of the 1-perfect and pluperfect (type III) in the Macedonian Ohrid dialect is non-confirmativity. As is known, nonconfirmativity as a feature of the verbal system is characteristic of the Balkan Slavic languages (Macedonian and Bulgarian), Turkish, and several Caucasian languages. In other Balkan languages (Albanian, Greek, Romanian, Meglenoromanian, Aromanian), non-confirmativity is not grammaticalized.

Because of the penetration of constructions of the type imam/sum + participle, the l-participle in the Macedonian Ohrid dialect became means of expression for both non-confirmativity and the admirative. But the Farsheroti Aromanian did not have non-confirmativity and the forms of the perfect covered only renarration (indeterminateness). In this case as well, the Farsheroti Aromanian approximated the Macedonian understanding 
of non-confirmativity through the borrowing of the formal indicators from Albanian. Thus, for the signification of non-confirmativity in the perfect, it used the admirative forms taken from Albanian.

For example:

тас. Кај комшиите имало куќа, што била многу сиромашна. arom. Tu kum'šăc a've 'ună 'kasă, ci 'fuska 'multu 'orfănă.

тас. Дедо ми порано имал илјада овщи. arom. Рари ńu a'meu v'lora a'vuska, ună ,nil'a di ŏ̌.

тас. Тој поминал многу време во затвор. arom. Năs tăr'kucka mult 'k'irou tu hăpsă'nă.

тас. Имам слушнато дека Тома за ништо ја запалил куќата. arom. Am av'dzată ka Toma ti nkot o aprin'dzeska ,kasa.

By this, the Farsheroti Aromanian form the Ohrid-Struga region is the only non-Slavic Balkan language which has grammaticalized the nonconfirmativity. Likewise, by this it is demonstrated that there exists a close relationship between the admirative and non-confirmativity. In the past, also the Albanian admirative has been used for non-confirmativity. In this framework, we can speak of an Albanian-Aromanian-Macedonian parallel.

From all this, it follows that with the compound past tenses there was a tendency to arrive at some common system, using their own and adopting foreign means, as was the case with Aromanian borrowing Albanian forms and models. The Macedonian Ohrid dialect, on the other hand, took the constructions with imam and sum and filled out gaps in its own tense system. It has taken advantage from the labile position of the 1-perfect and has used it for both non-confirmativity and for the admirative. The Farsheroti Aromanian directly took the Albanian forms for the admirative (albeit partially) and the models for the aorist pluperfect and used them in order to approximate the Macedonian system. Thus, now we have one Aromanian-Macedonian system where the compound past tenses may be said to be almost identical.

\section{Conclusion:}

All mentioned above demonstrates that the interference between Macedonian (on dialect level) and the Aromanian was very strong and penetrated deeply into the structure of both systems. By this the magnitude of the need for mutual understanding and communication is demonstrated. 
The features which were explained in this paper show that at a dialect level, the processes of interlingual interference are still active in some regions of the Balkan peninsula.

In this context, I would like to emphasize that this doesn't mean isolation of this dialect (Farsheroti Aromanian) in global frame, (in Balkan Sprachbund). The changes that took place in phonology, penetrated morphology, and remained within its system. From a general perspective, we can say that in the discussed Balkan microsyistems two tendencies exist:

The first - which concerns relations between phonological and morphological level - aims to strengthen the system and to enable easier communication between speakers of the microsystem in question;

The second - which penetrates deeper the language structure and connects morphology with syntax's into one system - morphosyntax, (such as for example the analytical declension) - aims to enable easier communication between speakers of different microsystems (and the whole language systems) on the Balkan area.

And this tendency towards easier communication is the essence of the Balkan Sprachbund.

\section{Bibliography}

Atanasov P.

(2002) Meglenoromâna astâzi, Bucureşti.

Балканскаяя филология

(1970) отв. редактор А. В. Десницкая, Ленинград.

Capidan Th.

(1932) Aromâni, Dialectul aromân, Bucureşti.

Caragiu-Marioteanu M.

(1968) Fono-morfologie aromânâ, Bucureşti.

Comrie B.

(1976) Aspect, Cambridge.

Cristo-Loveanu E.

(1962) The Romanian Language, New York.

Черняк А. Б.

(1990) Арумьнский язік, Ленинград.

Демирај Ш.

(1994) Балканска лингвистика, Скопје.

Fiedler W.

(1968) Das aromunische Verbalsystem in balkanologischer Sicht, Berlin.

(1968) Zu einigen problemen des admirativs in den Balkansprachen, Actes du premier congrès international des études Balkaniques et sud-est européennes, VI, Sofia. 
Fiedler W., Bucholz O.

(1987) Albanische Gramatik, Leipzig.

Friedman A.V.

(1977) The Gramatical Categories of the Macedonian Indicative, Columbus, Ohio.

(1981) The Pluperfect in Albanian and Macedonian, Folia Slavica, vol. 4, 2-3.

(1983) Gramatical Categories and a Comparative Balcan Grammar, Ziele und Wege der Balkanlinguistik, Berlin

(1994) "Surprise! Surprise! Arumanian has had an Admirative!", Indiana Slavic Studies, vol. 7, pp. 79-89.

(1996) A newly discovered gramatical form in the Arumanian dialect of Beala de Sus, The Newsletter of the Society Farsarotul, vol. X, issue 2, Trumbull CT.

(2001) "The Vlach Minority in Macedonia: Language, Identity, Dialectology, and Standardization", [in:] J. Nuorluoto, Martii Leiwo, Jussi Halla-aho (eds.), Selected Papers in Slavic, Balkan, and Balkan Studies, Slavica Helsingiensa 21, Helsinki, pp. 26-50.

Фридман А.B.

(1980) Адмиративот во балканските јазиии: категорија против употреба, Македонски јазик XXXI, Скопје.

(2001) Граматикализацијата на балканизмите во македонскиот јазик Македонски јазик, бр. 51-52, 31-38.

Галтон Х.

(1974) Кратка теоријаза македонскиот глаголски вид, Прилози V 1-2, Скопје. Galton H.

(1976) The main functions of the Slavic verbal Aspect, Skopje.

Георгиев В.

(1972) К вопросу о балканском языковом союзе, Новое в лингвистике, выпуск VI, Москва.

Голомб 3.

(1970) За «механизмот» на словенско-романските односи на Балканскиот полуостров, Македонски јазик, год. XXI, Скопје.

(1974) Значенето на македонскиот јазик за балканистичките студии, Пристапни предавања на новите членови на МАНУ, Скопје.

Gołąb Z.

(1961) Szkic dialektu Arumunów macedońskich, Prace językoznawce, zeszyt 4, Kraków.

(1984) The Arumanian dialect of Kruševo in SRMacedonia SFRYugoslavia, Skopje.

Ianachieschi-Vlahu I.

(1993) Gramatica armaneasca, Crushuva.

Илиевски Хр. П.

(1988) Балканолочки лингвистички студии, Скопје.

Јашар-Настева О.

(1989) Местото на македонскиот јазик во Балканската јазична заеднииа, Предавања на XXII семинар за македонски јазик, литература и култура, Охрид.

Koneski B., Vidoeski B., Jašar-Nasteva O. (eds.)

(1968) Distribution des Balkanismes en Macédonien, Actes du premier congrès international des études Balkaniques et sud-est européennes, VI, Sofia. 
Конески Бл.

(1981) Граматика на македонскиот јазик, Скопје.

(1982) Историја на македонскиот јазик, Скопје.

Корончевски А.

(1979) Македонската конструкција имам+раrticipium praeteriti како балканизам, Македонски јазик, год XXX, Скопје.

Kravar M.

(1980) Pitanja glagolskog vida u latinskom jeziku, Živa antika 6, Skopje.

Марковиќ М.

(2007) Ароманскиот и македонскиот говор од охридско-струшкиот регион (во балкански контекст), 188 стр., Скопје.

Mioara A.

(1986) Gramatica pentru toţi, Bucureşti.

Настев Б.

(1988) Аромански студии, Скопје.

Papahagi T.

(1974) Dicţionarul dialectului aroman, Bucureşti.

Тополињска 3.

(1992) За прагматичната и семантичната мотивација на морфосинтаксички балканизми, Прилози XVI, Скопје.

Topolińska Z.

(1995) Zarys gramatyki języka macedońskiego, Kraków.

Трајановски Т.

(1979) Влашките родови во Струшко, НИО «Просветен работник», Скопје.

(1998) Народните обичаи кај Власите од струшко, Друштво за наука и уметност «Браќа Миладиновци», Струга.

(1999) Власите во Охрид, Охрид.

Trifunoski J.

(1971) Die Arumunen in Mazedonien, Balcanica II, Beograd.

Трпкоски В.

(1986) Власите на Балканот, Скопје.

Weigand G.

(1891) Vlacho-Meglen, Leipzig.

(1895) Die Aromunen I, II, Leipzig.

Weinreich U.

(1970) Languages in Contact, Hague.

Видоески Б.

(1977) Тенденции во развојот на македонскиот дијалектен јазик во ХIX и XX век, Прилози II 1-2, Скопје.

(1984) Охридско-струшките говори, Прилози IX 1, Скопје.

(1985) Местото на охридскиот говор во западното наречје, Предавања на XVII семинар за македонски јазик, литература и култура, Охрид, 3-24 VII 1984, Скопје.

(1985) Македонските дијалекти во Албанија, Литературен збор, год. XXXII, Скопје. 
(1988) Југозападните македонски дијалекти со посебен осврт на битолското говорно подрачје, посебен отпечаток, Скопје.

(1993) Меѓујазичниот контакт (на дијалектно рамниште) како фактор за дијалектна диференцијација на македонскиот јазик, Реферати на македонските слависти за XI меѓународен славистички конгрес во Братислава, посебен отпечаток, Скопје.

Winnifrith T. J.

(1987) The Vlachs, The History of a Balkan People, London.

\section{Говорот на Ароманците Фаршероти - Балканска перспектива}

Во центарот на вниманието е анализата на говорот на Ароманците Фаршероти од охридско-струшкиот регион кој досега не бил предмет на посебна лингвистичка анализа. Тој говор се опишува во споредба со македонските охридско-струшки говори со посебен осврт кон нивните заемни интерференции врз балкански фон. Со тој пристап, појасно се истакнуваат паралелите и разликите меѓу овие говори и се добива поширока слика за процесите типични за Балканската јазична заедница.

Настојувањата за доближување до еден заеднички модел за овозможување на полесна и непречена комуникација биле најсилни кај оние јазични црти и категории кои биле во извесна мерка најоддалечени или сосема различни. И ароманскиот и македонскиот охридски говор се приспособувале еден кон друг притоа користејќи ги сите расположливи јазични средства и тоа не само од својот јазик. Така на пример, ароманскиот охридски ги елиминирал падежните наставки за генитив / датив и со тоа многу се доближил до аналитичката деклинација каква што е во македонскиот.

Исто така, и за сложените минати времиња од денешен аспект можеме да зборуваме за еден скоро заеднички албанско-ароманско-македонски модел. Ароманскиот говор на Фаршеротите, користејќи ги своите и преземените албански јазични средства создал таков модел, а македонскиот охридски, од друга страна, преземајќи ги конструкциите со имам и сум, ги пополнил празнините во својот глаголски временски систем. Како карактеристични можеме да ги земеме и адмиративните конструкции кои ароманскиот ги презел од албанскиот, а ги вклопил во македонскиот систем.

Сето ова покажува дека интерференцијата во рамките на микросистемите била многу силна и навлегла длабоко во нивната структура. Со тоа всушност се покажува големината на потребата за заедничко поимање на светот кое произлегува од потребата за полесна меѓусебна комуникација. 


\section{Dialekt Arumunów Farszerotów - Perspektywa bałkańska}

Przedmiotem niniejszej analizy jest dialekt Arumunów Farszerotów z rejonu Ochrydy i Strugi (Republika Macedonia), który dotychczas nie był przedmiotem oddzielnej analizy lingwistycznej. Dialekt Farszerotów opisywany jest w konfrontacji z macedońskimi dialektami ochrydzko-strużkimi, przy czym szczególną uwagę zwraca się na wzajemne interferencje na tle bałkańskim. W ten sposób wyraźniej widoczne stają się podobieństwa i różnice pomiędzy tymi dwoma dialektami dzięki czemu zyskujemy szerszy obraz procesów typowych dla bałkańskiej ligi językowej.

Najsilniejsze tendencje zmierzające do stworzenia wspólnego modelu umożliwiającego łatwiejszą i stałą komunikację odnotowano w obrębie tych cech i kategorii językowych, które były najbardziej oddalone od siebie albo całkowicie różne. I arumuński i ochrydzki macedoński upodobniały się do siebie, wykorzystując wszystkie środki językowe nie tylko z zaplecza jakim był własny język. I tak np. ochrydzki arumuński wyeliminował końcówki genetivu i dativu i w ten sposób bardzo zbliżył się do analitycznej deklinacji typowej dla języka macedońskiego.

Podobnie możemy mówić o wspólnym albańsko-arumuńsko-macedońskim modelu w odniesieniu do czasów przeszłych złożonych. Arumuński dialekt Farszerotów stworzył taki model, wykorzystując własne i zapożyczone z albańskiego środki językowe. Z drugiej zaś strony ochrydzki macedoński, przejmując konstrukcje z imam i sum wypełnił brakujące miejsca we własnym systemie czasów. Jako typowy przykład można podać konstrukcje admiratywne, które arumuński przejął od albańskiego, a jednocześnie za jego pośrednictwem konstrukcje te zostały wprowadzone do systemu języka macedońskiego.

Wszystko to uświadamia nam, że interferencja w ramach mikrosysetmów była bardzo silna i głęboko weszła w ich strukturę. W ten sposób ujawnia się doniosłość jednakowego rozumienia świata, wynikające z potrzeby łatwiejszej komunikacji wzajemnej.

Przekład z języka macedońskiego Jolanta Sujecka

\section{The Aromanian Farsheroti Dialect - Balkan Perspective}

The focus of our interest is the analysis of the Aromanian Farsheroti speech from the Ohrid-Struga region, which has never been a subject of a separate linguistic analysis. This speech is described in comparison to the Macedonian Ohrid-Struga dialects and special emphasis is given to their mutual interferences within the Balkan context. Using such approach, the parallel structures and the differences between these speeches are more clearly pointed out thus presenting a wider picture of the processes typical of the Balkan linguistic community. 
The efforts for drawing closer to a joint model that enables easier and straightforward communication were the most powerful with the linguistic features and categories that were in a way the most distinct and completely different. Both Aromanian Farsheroti and Macedonian Ohrid speeches adjusted to each other by using all available linguistic means not only from their own languages. For instance, the Aromanian Farsheroti speech has eliminated the case inflections for genitive / dative thus approaching closer to the analytical declination which is the case with the Macedonian language.

Even for the complex past tenses from a present point of view can be argued that they outline an almost joint Albanian-Aromanian-Macedonian model. The Aromanian Farsheroti dialect, using its own and the borrowed Albanian linguistic characteristics, has created such model, whereas the Macedonian Ohrid speech, on the other hand, by adopting the constructions with imam (have) and sum (be), has filled the blanks in its own verbal tense system. The constructions showing admirative are another typical feature that the Aromanian has borrowed from the Albanian and has incorporated into the Macedonian system.

All these instances show that the mutual interference was very strong and emerged deeply in the structure of the two systems. This is another proof of the great need for mutual conception of the world which is a result of the need for easier mutual communication.

Key words: Aromanian, areal linguistics, Balkan linguistics, Macedonian dialectology, language typology 